\title{
PENGEMBANGAN PENDIDIKAN ISLAM MULTIKULTURAL DI ERA MODERN
}

\author{
Ainur Rofiq, Evi Fatimatuzhuro \\ Institut KH. Abdul Chalim \\ ainur.rofiqjembul@gmail.com,Zuhro008@gmail.com
}

Diterima: 24 Mei 2019 | Direvisi: 27 Mei 2019 | Disetujui: 37 Mei 2019

(C) 2018 Program Studi Pendidikan Agama Islam Fakultas Agama Islam Universitas Islam Malang

\begin{abstract}
Every country, region, topography or appearance form of an area influences the pattern of life of its people, and also influences their way of life, let alone Indonesia which has thousands of islands, various tribes, ethnicities, languages, cultures, even religions. This also makes the customs and culture of society different, culture is created because of human existence. It is human beings who can shape their own culture and the people themselves who use that culture as well, therefore culture will always exist and develop along with the existence and development of humans in each region. Diversity in society is a necessity that cannot be separated from Indonesian national identity. diversity can be said to be the spirit and identity of the community which is a reference to the orientation of values, norms, rules, and guidelines for the daily behavior of members of society in living in groups and in personal life. Then the position of multicultural educators is essential in Islamic education that will be able to answer a problem that has been divided so far due to differences in ethnicity, language, religion, and culture. This multicultural education will be able to glue and also unite the differences of the people of a nation, especially this beloved Indonesian nation, which in fact has and has a variety of ethnic, ethnic, religious, linguistic and cultural communities.
\end{abstract}

Keyword: Development, Multikultural, Modern

\section{Pendahuluan}

Indonesia adalah bangsa yang majemuk dan memiliki keragaman ras, budaya, suku, bahasa, adat istiadat maupun keyakinan yang berbeda-beda, hal tersebut dilihat dari sudut horizontal.Dari sudut vertikal, keberagaman yang ada di Indonesia dapat dilihat dari tingkat pekerjaannya, tingkat ekonomi, pendidikan, dan kultur sosial yang ada di masyarakat Indonesia (Ida Zahara Adibah, 2016).

Pendidikan ialah hal yang mendasar dan bagian yang terpenting dalam menjalani kehidupan. Karena, pendidikan merupakan sebuah proses dalam mengembangkan sumber daya manusia supaya mendapat kemampuan sosial yang tinggi, dan mengoptimalkan individu menjalin hubungan yang 
kuat dengan individu lainnya dan dengan masyarakat maupun dengan lingkungan sekitarnya (Rustam Ibrahim, 2013: 54-129). Dari hal tersebut maka, dalam mempertahankan tradisi dan keragaman yang ada yaitu dengan melalui jalan pendidikan. Karena pendidikan merupakan alat yang sangat penting dalam mengembangkan, mempertahankan, dan menyatukan tradisi yang ada dari genersi terdahulu hingga ke generasi selanjutnya (Achmad Rois, 2013: 305).

Di era modern inipendidikan Islam juga merupakan sebagai aspek yang penting sebagai landasan agar manusia tidak kehilangan moral yang semakin hari kian terkikis dan begitu memprihatinkan. Dalam hal ini pendidikan Islam sangat berperan aktif agar terciptanya insan kamil yang sesungguhnya. Indonesia merupakan negara yang besar dan yang multikultural, yang memiliki berbagai keragaman seperti budaya, ras, suku, dan agama.Hal tersebut tentu menarik perhatian kita dan menjadi titik persoalan yang akan menjadikan perbedaan di antara satu dengan yang lain. Ketika tidak mampu saling menghargai dengan yang lain tentu berbagai perselisihan itu terjadi, yang akan membuat banyak konflik dan perpecahan akan terjadi. Di era yang modern ini tentu kita harus mengantisipasi hal tersebut dengan saling menumbuhkan rasa saling menghormati dan menghargai keberagaman yang ada, sehingga konflikkonflik tidak akan muncul. Oleh karena itu perlu kita pelajari bagaimana pendidikan Islam multicultural dapat mempererat segala perbedaan yang ada di masyarakat. Sehingga menumbuhkan sikap toleransi yang tinggi dan tidak mudah untuk saling menyalahkan orang lain (Inayatul Ulya dan Ahmad Afnan Anshori, 2016: 23).

Dalam penelitian ini akan menjawab persoalan-persoalan tentang perbedaan suku, bahasa, agama, budaya yang selama ini dianggap oleh beberapa orang atau kelompok menjadi salah satu pemicu utama terjadinya perselishan yang mengakibatkan pertengkaran, perkelahian, permusuhan yang berkepanjangan, serta dalam tulisan ini juga ada perbedaan tertentu dengan artikel atau makalah yang lain. Dalam tulisan ini menjelaskan bahwasaannya perbedaan merupakan suatu keniscayaan dari yang maha kuasa sehingga perbedaan ini jangan dijadikan sebagai alasan perpecahan, permusuhan maupun pertengkaran terutama bangsa indonesia yang begitu kaya akan keragaman suku, etnis, bahasa, agama dan juga budaya, tapi justru keragaman itu muncul supaya kita saling mengenal dan memahami antara satu dengan yang lainnya walaupun terus menerus adanya perubahan zaman yang semakin canggih dan semakin modern saat ini, bahkan adanya propaganda dan fitnah yang intinya ingin memecah belah 
bangsa indonesia, dengan demikian akan timbul suatu kehidupan yang saling mengerti, menghargai, menyayangi dan juga memahami antar sesama sebagai satu kesatuan yang tercover dalam kerangka besar sebagai bangsa indonesia.

\section{Metode}

Dalam penelitian ini, peneliti menggunakan metode penelitian Kualitatif menggunakan pendekatan fenomenologi, dengan mengacu pada pendapat John W. Creswell, (Creswell, 1998) menyatakan; Pendekatan fenomenologi ialah suatu pendekatan yang mengurai ataupunmakna dalam sebuah konsep ataupun fenomena suatu pengalaman yang berdasarkan padu suatu kejadian yang dialami oleh seseorang atau individu. Pendekatan Fenomenologi ini juga dilaksankan pada situasi dan kondisi alamiah atau tidak direkayasa, hal ini menyebabkan seorang peneliti dalam konteks memahami dan juga memaknai suatu fenomena yang diteliti pembatas yang menghalanginya, serta para peneliti mempunyai kebebasan dalam menganlisa data-data atau dolumen-dokumen yang didapatinya.

Teknik dalam Pendekatan fenomenologi ini dapat menunda terhadap suatu penilaian terhadap sikap yang natural sampai dengan batas waktu ditemukannya dasar-dasar yang melandasinya, pemendingan ini disebut juga dengan istilah jangka waktu (epoche). Konsep epoche ialah memetakan kawasan subyek (data) menurut interpretasi dari masing-masing peneliti.Dalam Konsep epoche merupakan suatu pokok yang mana seorang peneliti mengelompokkan dan juga menyusun prasangka pertama tentang adanya fenomena guna untuk memahami tentang apa saja yang dibicarakan oleh para responden (Creswell, 1998).

\section{Pembahasan}

\section{Definisi pendidikan Islam}

Secara epistemologi, dapat dikatakan bahwa pendidikan dari kata educareyang berasaldari bahasa latin, yaitu yang artinya membimbing, membuka, dan mengarahkan manusia agar menjadi seseorang yang dapat mencapai potensi yang dimilikinya. Selain itu ada istilah yang mengatakan bahwa pendidikan disebut juga pedagogi atau pedagogic yang artinya ilmu dan seni mengajar anak (Heri Cahyono, 2017: 28).

Menurut Darmaningtyas, pendidikan didefinisikanyaitu bentuk usaha yang sengaja dilakukan dan sudah terencana agar dapat memperoleh kehidupan yang diinginkannya. Menurut koentjaraningrat, yaitu ahli antropologi di Indonesiayang menjelaskan bahwa pendidikan merupakan 
suatu usaha yang dilakukan agar dapat mengembangkan kultur budaya terdahulu untuk generasi yang sekarang(Achmad Rois, 2013: 305).

Jadi pendidikan merupakan hal yang sangat dibutuhkan oleh manusia, sebegitu pentingnya karena dengan adanya pendidikan dapat membawa manusia untuk selalu berpikiran terbuka dan dapat mencapai taraf kehidupan yang bahkan jauh lebih baik dari sebelumnya. Pendidikan mampu mencapai segala impian yang diangan-angankanya dan mampu diraihnya melalui dunia pendidikan. Pendidikan mampu melahirkan pemikiran-pemikiran yang baru yang dapat selalu berkembang dari generasi ke generasi yang selalu dapat mengejutkan mata dunia akan kehebatan dari dunia pendidikan.Ilmu memang dapat kita cari dimana saja dan kapan saja, namun dunia pendidikan merupakan wadah yang paling utama dalam mengembangkan segala potensi yang kita miliki.

Pendidikan Islam adalah usaha sadar yang terencana yang dilakukan dalammengarahkan dan mengembangkan manusia agar lebih baik yang berdasarkan nilai-nilai kehidupan yang baik serta akan terbentuk menjadi orang yang memiliki kepribadian yang sempurna, baik dalam hal akal, perbuatan, maupun perasaan.

Ahmad D. marimba berpendapat bahwa pendidikan Islam ialah membimbing atau memimpin dan mengarahkan perkembangan jasmani dan rohani peserta didik agar tercapainya kepribadian yang sempurna yaitu insan kamil.

Dalam ajaran islam tujuan dari diciptakannya manusia mempunyai sebuah tujuan, diantara tujuannya yaitu beribadah agar patuh dan tunduk kepada perintah Allah. Seperti firman Allah sebagai berikut:

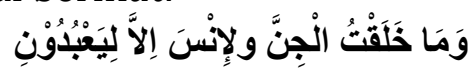

"Dan aku tidak menciptakan jin dan manusia melainkan supaya mereka beribadah kepada-Ku" (Q.S Az-Zariat/51:56)

Ahmad tafsir juga mendefinisikan pendidikan Islam ialah usaha yang dilakukan oleh pembimbing kepada orang lain agar bisa berkembang semaksimal mungkin dalam menjalankan syariat Islam(Abdur Rahman, 2012: 2055).

Menurut Fazlur rahman, pendidikan Islam bukan hanya sekedar sebuah pelengkapan ataupun kuasi fisik dalam sebuah pembelajaran misalnya buku pelajaran yang sudah pernah dipelajari maupun sudah tersrtuktur diluar pendidikan, melainkan intelektualisme keislaman.Maka dari hal tersebut, dapat dimaksudkan hakikat dari pendidikan Islam yang sebenarnya.Hal tersebut bentuk dari berkembangnya suatu ide pemikiran 
Islami yang murni dan memadai yang berkonstribusi dalam menilai suatu system pendidikan Islam (Ainul Khalim, 2015).

Azyumardi azara berpendapat bahwa pendidikan Islam adalah salah satu bentuk dari keseluruhan ajaran agama Islam.Sebab tujuan hidup manusia tidak terlepas dari tujuan pendidikan Islam itu sendiri, yang mampu mengembangkan dan membentuk manusia yang bertakwa.Untuk mendapatkan kehidupan yang damai dan bahagia baik di dunia maupun di akhiratnya.Tujuan hidup manusia yang sebenarnya ialah menjadi hamba yang bertakwa yang menjadi rahmatallil'alamin.

Dari beberapa pendapat tokoh seperti yang sudah disebutkandiatas mengenai definisi dari pendidikan Islam. Dapat disimpulkan bahwa pendidikan Islam adalah usaha yang dilakukan dan yang terencana dalam mengembangkan potensi yang dimilikinya agar menjadikan seseorang mempunyai kepribadian yang lebih baik, dan menjadikannya sebagai manusia yang sempurna (insan kamil) dan bertakwa kepada Allah Swt dan memperoleh kehidupan yang baik di dunia maupun diakhirat.

\section{Pendidikan Multikultural}

Secara epistimologi, multicultural berasal dari 2 kata yaitu multi yang artinya beragam, atau banyak, dan kultur yang artinya budaya. Multicultural memiliki arti penerimaanterhadap segala perbedaan manusia yang sesuai pada kebudayaan yang dimiliknya.Multicultural adalah sebuah paham tentang budaya yang beragam.Di dalam keragaman budaya itu ada yang namanya pemahaman, pengertian, saling toleransi agar terciptanya suatu hidup yang damai serta jauh dari konflik yang tak berujung (Indra Giri Hulu, 2016: 196).

Menurut Anderson dan Cusher, pendidikan multicultural adalah pendidikan sebagai keragaman dari banyak kebudayaan.Sedangkan menurut James Banks, pendidikan multicultural ialah pendidikan yang berfungsi untuk people of colour, artinya bahwa pendidikan multicultural mempunyai keinginan untuk mengeksplorasi segala perbedaan yang ada sebagai keniscayaan atau persatuan (Muhiddinur Kamal, 2013: 457).

Hilda Hernandez juga berpendapat di salah satu karyanya yang menjelaskan bahwa pendidikan multicultural sebagai pandangan yang mengakui adanya realitas sosial, ekonomi, dan politik yang akan dirasakan oleh seluruh manusia.

Dalam pandangan James, pendidikan multicultural dibagi menjadi beberapa dimensi yang akansaling berkaitan yaitu:

a. Content integrasi 
Ialah menghubungkan dari berbaagai budaya yang ada dan kelompokkelompok agar dapat menggambarkan konsep dasar, generalisasi dan isi materi yang ada di dalam buku pelajaran.

b. The knowledge contruction process

Ialah mengarahkan peserta didik agar dapat memahami keterlibatan budaya pada salah satu buku pelajaran.

c. An equity paedagogy

Ialah penyesuaian metode pembelajaranmelaluigaya atau cara belajar peserta didik yang bermacam-macam dari segi, ras, suku, budaya, ataupun socialnya.

\section{d. Prejudice reduction}

Ialah menemukan identitas karakteristik peserta didik dan menemukan metode pembelajaran yang akan digunakan.

Pendidikan multicultural adalah sebuah proses untuk mengembangkan seluruh potensi yang dimiliki oleh manusiayang saling menghargai perbedaan dan heterogen sebagai akibat perbedaan ragam ras, suku, budaya dan agama. Oleh sebab itu, pendidikan multicultural yang seperti disebutkan tadi memiliki konsekuensi yang luas dalam pendidikan. Sebab, secara umum dapat dipahami bahwa pendidikan merupakan proses yang tidak akan pernah berakhir ataupun bisa disebut sampai akhir hayat, karena pendidikan harus dapat membentuk diri menjadi manusia yang berbudi, bermoral, dan berakhlakhul karimah (Mohamad Yasin Yusuf, 2014: 199).

Pendidikan multicultural dapat membantu siswa dalam memahami, menerima, dan saling menghormati orang lain dari keberagaman yang ada. Sehingga akan ada sikap saling saling menghargai perbedaan dan bisa hidup rukun dengan saling berdampingan satu dengan yang lain.

Jadi, pendidikan multicultural ialah pendidikan yang berfokus pada keberagaman dan kesetaraan, karena semua orang mempunyai hak yang sama. Disini pendidikan multicultural akan menunjukkan bahwa perbedaan antar agama, suku, dan budaya tidak akan mempengaruhi hubungan yang terjalin antar sesama. Karena perbedaan yang ada dapat mempererat tali persaudaraan.Karena dengan hal itu, kita bisa saling memahami, mengerti dan belajar bersama untuk dapat berinteraksi dengan baik.Diharapkan pendidikan multicultural memberi wawasan baru pada pandangan masyarakat yang terlalu menggul-unggulkan kelompok, suku, maupun budayanya sendiri tanpa melihat betapa banyak perbedaan dan keragaman yang indah di luar sana dan dengan begitu seluruh masyarakat dapat 
menikmati keberagaman yang ada, tanpa adanyatindakan saling menyakiti ataupun menimbulkan konflik antar kelompok.

Tujuan dari pendidikan multicultural untuk mengembangkan seluruh potensi yang dimiliki peserta didik untuk mengembangkan seluruh potensi yang dimiliki oleh peserta didik agar perdamaian dalam segala perbedaan.Tuhan telah menciptakan manusia berbeda-beda sesuai dengan kelemahan dan kelebihan masing-masing.Begitu juga dengan yang sudah diberikan Tuhan kepada kita, lingkungan merupakan hal berpengaruh dalam mengembangkan seluruh potensi individu maupun social.Hingga, gagasan multicultural adalah salah satu contoh bahwa lingkungan salah satu hal yang mempengaruhi pengembangan potensi.

Ada beberapa hal dalam pembelajaran yang harus difokuskan guru agama terhadap peserta didik mengenai pendidikan multikultural, yaitu:

a. Pembelajaran perdamaian

Jevier berpendapat bahwa kedamaian itu dibentuk dari diri kita sendiri.Dengan berpikir dan pemaknaan yang tenang dan damai.Hal tersebut akan menimbulkan berbagai cara yang baru dan akan memunculkan kreatifitas untuk mengembangkan kerja sama antar seluruh kelompok.Untuk bisa menjalani kehidupan secara bersama-sama kita membutuhkan perdamaian.

b. Pembelajaran tentang hak asasi manusia

Seluruh manusia memiliki hak yang sama, tidak dapat dibagi, namun saling terkait. Alat yang paling efektif dalam mengembangkan nilai dan hak asasi manusia adalah pendidikan.Dalam hal ini, dijelaskan bahwa hak asasi yang dimiliki oleh manusia itu harus dapat mengembangkan berbagai cara pandangnya untuk saling melindungi hak anak, perempuan, kaum minoritas dan lain-lain.

c. Pembelajaran demokrasi

Pada hakekatnya, pola pikir manusia tentu menginginkan adanya sikap saling toleransi, saling percaya, dan menghargai budaya dan perbedaan keyakinan dan segala bentuk perbedaan yang ada. Dalam hal ini, ketika semua orang menyadari akan pentingnya hal tersebut. Tentu akan lebih mudah dalam mengambil suatu keputusan yang lebih baik. Karena hal tersebut akan menunjukkan pada kita adanya rasa damai dan adil.

\section{Pentingnya pendidikan multicultural di era modern}

Indonesia adalah Negara yang majemuk dan multicultural.Majemuk disini berarti bangsa yang mempunyai masyarakat yang berbeda budaya, ras, suku, dan keyakinan.Kepentingan masyarakatnya pun berbeda-beda, yang hidup dalam individu-individu namun dalam satuan politik. 
Kemajemukan disini digambarkan seperti pisau yang memiliki dua sisi yang akan menunjukkan dampak potif ataupun dampak negatifnya. Karena keragaman sangat rawan dengan terjadinya konflik yang ada dimasyarakat yang akan berdampak buruk pada social, politik, dan ekonomi (Ulya and Anshori, 2016).

Multicultural merupakan rancangan yang bisamenjawab perubahan zaman, karena multicultural merupakan sistem yang mengunggulkan keragaman kultur, atau sebuah kepercayaan yang mendorong dan mengakui adanyaperbedaan budaya dalam masyarakat.Multicultural dapat dijadikan jembatan dan pengikat yang dapat memfasilitasi segala kesukubangsaan yang ada (Edy, 2017: 100).

Untuk menyikapi hal tersebut, perlu adanya strategi baru dan cara berfikir yang lebih toleransi yang akan mencegah adanya perselisihan antar budaya pada kelompok tertentu dan menjauhi sikap fanatisme pada kelompok sendiri. Sehingga semua perbedaan tidak akan menimbulkan konflik yang akan memecah belah suatu persatuan bangsa

Di era modern ini,masyarakat kota umumnya melakukan banyak perubahan-perubahan yang menjadikan mereka lebih cepat dalam memutuskan suatu masalah dan dapat membangun sebuah kesatuan. Namun, masyarakat kotasudah tidak mempercayai lagi hal-hal yang irasional seperti halnya masyarakat tradisional. Mereka hanya mempercayai hal-hal yang rasional saja.Pemikiran yang rasional mempengaruhi pada perkembangan karakter dan pada apa yang menjadi tujuannya di masa depan (Zulkarnaini, 2015: 153).

Masyarakat modern memiliki ciri-ciri seperti di bawah ini: pertama, hubungan yang ada antara individu ada atas dasar kepentingan pribadi saja. Kedua, hubungan masyarakat yang mudah saling memengaruhi oleh orang lain. Ketiga, kepercayaan penuh pada perkembangan teknologi dan ilmu pengetahuan yang bisa meningkatkan kesejahteraan masyarakat. Keempat, masyarakat kota memiliki banyak profesi yang bisa dipelajari dalam lembaga pendidikan, kejuaruan, maupun keterampilan. Kelima, memiliki tingkat pendidikan formal yangtinggi.Keenam, peraturan yang berlaku adalah peraturan yang tertulis dan lengkap(Zulkarnaini, 2015).

Masyarakat modern memang berbeda dengan masyarakat tradisional, dengan adanya kemajuan zaman yang pesat dan apapun bisa di dapat dengan mudah karena perkembangan teknologi yang ada.Namun dengan adanya kemajuan teknologi yang tinggi hubungan interaksi antar sesama juga tidak begitu diperhatikan. Karena semuanya sudah merasa tidak membutuhkan bantuan orang lain. Padahal manusia adalah makhluk social 
yang akan saling membutuhkan bantuan orang lain. Di era modern ini pendidikan multicultural sangat penting dan berpengaruh, karena dapat membangun bagaimana hubungan interaksi yang baik dan tentunya dapat menghormati orang lain.

Dalam hal ini pendidikan multikultual bisa menjadi media yang dapat membangun kesadaran betapa pentingnya multikulturalisme.Pendidikan sangat memegang peranan penting dalam membangun eksistensi dan perkembangan suatu masyarakat.

Urgensi pendidikan multicultural dapat dibagi menjadi dua, yaitu:

a. Sarana untuk memecahkan masalah

Budaya Indonesia sangatlah beragam, oleh karena itu menjadi tantangan bagi dunia pendidikan.Agar bisa menghindari sebuah perbedaan dan menjadi kesatuan.

Dalam dunia pendidikan, pendidikan multicultural dapat menjadi jalan dari pemecahan masalah yang ada di masyarakat.Dan bisa menjadi solusi dari pemecahan konflik social budaya yang ada di masyarakat.Perubahan yang selalu diharapkan dalam sebuah pembelajaran multicultural ialah terletak pada bagaimana terciptanya keadaan yang damai, dan saling menghormati dalam keberagaman.

Dengan memberi berbagai contoh dan pembelajaran yang baik, dunia pendidikan akandapat menciptakan perubahan yang lebih baik dan menjadikan kedamaian dan ketentraman bagi masyarakat.

b. Agar peserta didik tidak tercabut dari akar budayanya sendiri

Di era globalisasi dan modern ini, segala sesuatu dapat di peroleh dengan mudah.Terutama dengan adanya IPTEK yang semakin berkembang.Tetapi dibalik itu semua, pertemuan antar berbagai budaya juga memberikan dampak dan ancaman bagi generasi muda.Dalam menyikapi hal tersebut, peserta didik hendaknya menyadari akan pengetahuan tentang keberagaman, sehingga dapat memiliki pengetahuan yang luas dan global.

\section{Pengembangan Pendidikan Islam Multikutural}

Adanya konstruk dalam pendidikan Islam multicultural membawa pada tatanan struktur yang baru dalam pendidikan yang memiliki karakteristik plural dan membawa nilai-nilai yang mengandung kearifan dalam perbedaan budaya. Konstruk dalam pendidikan ini diyakini akan bisa menyokong terbentuknya masyarakat yang multikulturalisme maupun pluralism. Perdamaian akan tercipta ketika seluruh masyarakat mengerti bahwa manusia tidak dapat hidup secara individual dan selalu membutuhkan bantuan orang lain (Jasmani, 2015: 94). 
Jika ada keinginan untuk merekonstruksi pendidikan Islam multikulturalisme dalam maksud nilai yang akandisampaikan dalam hal pendidikan maupun dalam konteks keberagaman budaya. Maka dalam hal ini yang akan muncul adalah dalam masalah pemahaman seputar teologi yang masih di dalam hal tentang klaim kebenaran untuk dirinya sendiri, sehingga nilai-nilai yang akan timbul ialah pihak lain yang berkeyakinan diluar agamanya dianggap salah.

Konstruksi ilmu pengetahuan yang lahir akan mendorong pendidikan Islam multicultural lebih menemukan titik tentu sebagai gerbang ilmu pengetahuan terkhusus dalam hal ilmu pengetahuan keislaman yang komprehensif dan solutif dengan latar kearifan kebudayaan. Hal tersebut akan berdampak pada proses konversi lembaga pendidikan akan memfokuskan pada pengembangan ilmu pengetahuan dalam membangun masyarakat yang majemuk (Jasmani, 2015: 94).

\section{Prinsip Pendidikan Islam Multicultural}

Dalam mengembangkan pendidikan Islam multicultural, sudah sepatutnya mempertimbangkan prinsip-prinsip pendidikan multicultural, yaitu:

a. Pendidikan multicultural mempunyai tujuan agar seluruh masyarakat tidak merasakan adanya deskriminasi dalam segala perbedaan yang ada.

b. Pendidikan multicultural mengandung 2 bentuk dimensi, antara lain: pembelajaran, kelembagaan. Keduanya saling memiliki keterkaitan. Untuk menanganinya memerlukan perubahan yang luas dan menyeluruh.

c. Pendidikan multicultural lebih mengarah pada perubahan pendidikan yang luas dan menyeluruh yang hanya bisa dilakukan dengan mengamati secara teliti dan cermat.

d. Dari analisis tersebut, bisa difahami bahwa tujuan pendidikan multicultural ialah untuk menyediakan setiap peserta didik jaminan untuk memperoleh kesempatan yang bertujuan untuk mencapai prestasi maksimal sesuai dengan kemampuan yang dimilikinya.

e. Pendidikan multicultural ialah pendidikan yang baik bagi seluruh peserta didik tanpa memandang latar belakang mereka.

Untuk menunjukkan ciri khas dari pendidikan Islam, perlu adanya pengembangan kurikulum pendidikan Islam, seperti pendapat Al-Syaibani sebagai berikut:

a. Lebih mengarah pada unsur Islami, semua yang yang berhubungan dengan proses belajar dan pembelajaran mengarah pada nilai sikap dan ajaran agama. 
b. Berprinsip umum dengan segala bentuk isi dan tujuan dari kurikulum.

c. Berpinsip yang sesuai dengan adanya bentuk isi dan tujuan dari kurikulum.

d. Berprinsip pada hubungan yang ada pada peserta didik dengan apa yang dibutuhkan oleh masyarakat.

e. Berrinsip toleransi terhadap keragaman yang ada pada peserta didik, misalnya kompetensi masing-masing , minat dan bakatnya.

f. Beprinsip merubah dan mengembangkan nilai-nilai yang sudah ada.

g. Beprinsip adanya keterkaitan dalam mata pelajaran, aktivitas, dan pengalaman yang di terima di dalam kurikulum. Begitu juga dengan keterkaitan antara isi dari kurikulum dengan kebutuhan peserta didik dan masyarakat.

Pengembangan pendidikan Islam dapat di dasarkan pada prinsipprinsip pendidikan Islam multicultural. Sebagaimana seperti pendapat Daradjat sebagai berikut:

a. Prinsip keterkaitan

Maksudnya ialah pendidikan dapat mengaitkan dengan kehidupan peserta didik untuk dirinya yang sekarang, di masa depan, dan tuntutan pekerjaan.

b. Prinsip keefektifan

Maksudnya ialah terdapat dampak atau hasil yang baik bagi peserta didik dan guru yang membimbing.

c. Prinsip ketepatan

Maksudnya ialah ketepatan dalam mengelola biaya, waktu, dan tenaga.

d. Prinsip fleksibilitas

Terdapat kebebasan dalam mengelola program pembelajaran maupun mengembangkan program pembelajaran yang sesuai.

Dengan adanya keempat prinsip tersebut diharapkan pengembangan pendidikan Islam multicultural memiliki signifikasi yang maksimal dalam menjadikan peserta didik yang multicultural Islami.

\section{Tantangan Pengembangan Pendidikan Islam Multikultural}

Pendidikan Islam multicultural di Indonesia merupakan hal yang relative baru. Akan tetapi sudah sejak belasan abad lamanya seluruh umat muslim mempelajari Al-qur'an dan hadis yang menjadi dasar atau pondasi ajaran-ajaran Islam dalam kehidupannya. Karena di dalam Al-qur'an dan hadis juga sudah dijelaskan bagaimana sikap saling menghormati dan menghargai perbedaan antar sesame (Hefni Zaini, 2013: 119). 
Sampai saat ini, banyak bermunculan gagasan dan konsep dari pendidikan Islam multicultural yang terus dikembangkan.Keberadaannya memberikan dampak yang positif dalam mengembangkan ajaran-ajaran Islam dan hubungannya dengan masyarakat di era modern.Hal tersebut dapat menjawab tantangan hidup pada era modern saat ini, dimana kehidupan berkembang sangat cepat dan tanpa batas.Semua membutuhkan kesadaran pada dirinya sendiri yang berkaitan dengan keragaman dan perbedaan yang perlu untuk dihormati dan dihargai (Hefni Zaini, 2013: 119).

Upaya dalam mengembangkan pendidikan Islam multicultural tidaklah semudah membalikkan tangan, tentu ada banyak tantangan yang harus dihadapi dan bahkan bisa memperlambat ataupun menghambat dalam proses perjalanannya. Berikut ini adalah beberapa tantangan yang mungkin dihadapi:

a. Aspek Sosio-kultural

Ialah aspek dari komponen yang ada di masyarakat yang muncul karena adanya kelompok-kelompok yang masih berpandangan kuno,baik kelompok non muslim ataupun muslim dalam menanggapi adanya pendidikan Islam multicultural. Persoalan ini sudah ada sejak dulu, karena adanya perbedaan dalam memahami teks-teks dalam pewahyuan. Dengan adanya multicultural, sebagian kelompok dikhawatirkan akan melemahkan kepercayaannya terhadap agamanya.

b. Aspek politik

Ialah aspek yang terdapat pada pembuatan kebijakan pendidikan.Dimana di dalamnya memuat tentang adanya pendidikan Islam dan menghubungkannya dengan pentingnya pendidikan multicultural bagi peserta didik, tentu membutuhkan waktu yang lama dalam menjalankannya.Namun itu semua sangat berpengaruh terhadap penerapan kebijakan pendidikan multicultural dalam dunia pendidikan.

c. Aspek pendidikan

Ialah termasuk aspek mengenai lembaga pendidikan, dimana sebagian lembaga pendidikan kesulitan dalam mengolah dan mengembangkan pendidikan multicultural.Karena keduanya memiliki perbedaan. Sehingga hal tersebut berpengaruh menghambat dan mempengaruhi pada proses penerapannya di lapangan.

Dari beberapa hal sudah diuraikan, ada beberapa hal yang perlu diperhatikan untuk dapat mengembangan pendidikan Islam multicultural di Indonesia, yaitu : 
Pertama, pendidikan multicultural sudah berhubungan erat sejak Indonesia ada.Yaitu bisa dilihat di falsafah bangsa Indonesia "Bhineka Tunggal Ika", saling membantu, suka bergotong-royong, dan saling menghargai antara suku.Hal tersebut akan dapat menyatukan dan mengembangkan pendidikan multicultural yang ada di Indonesia.

Kedua, pendidikan multicultural bisa menjadi solusi konflik yang terbaik yang ada di masyarakat pada akhir-akhir ini.Karena pendidikan multicultural sangat pluralitas dalam keragaman, dan sangat memperhatikan nilai-nilai yang ada di masyarakat.Untuk mendalami pendidikan Islam multikltural, dapat dicari dan dikupas dari segala sumber ajaran Islam, yaitu Al-Qur'an dan hadis. Jika hal tersebut dilakukan, itu akan menjadi kajian yang menarik dan akan menjadikan kaum muslim lebih memahami nilai ajaran-ajaran dalam agamanya.

Ketiga, perlu adanya tindak lanjut yang dapat menjadikan pendidikan multicultural dapat dipahami dan diterapkan langsung di dalam masyarakat.

Dari beberapa uraian yang telah disebutkan bahwa untuk mengembangkan pendidikan Islam multicultural tidaklah mudah, semua mempunyai peran untuk menciptakan kondisi yang mutikultural. Segala yang diupayakan akan mempunyai banyak dampak yang positif dalam mengembangkan pendidikan Islam multicultural. Banyak aspek yang mempengaruhi dan menjadi tantangan, namun ketika semua orang memahami dan dapat mempersatukan semua ke dalam wadah yang tepat, tentu segala tantangan dan rintangan yang ada dapat diselesaikan dengan adanya kesatuan yang timbul dalam masyarakat maupun dari segala pihak.Oleh karena itu, mengingat betapa pentingnya pendidikan Islam multicultural, perlu adanya tantangan yang akan dapat menjadikan pendidikan Islam multicultural lebih berkembang menjadi lebih baik dan dapat diterapkan dengan sebaik-baiknya dalam kehidupan bermasyarakat.

\section{Kesimpulan}

Pendidikan Islam multicultural adalah pendidikan yang menekankan pada pada aspek keberagaman yang ada, dimana keberagaman tidaklah menjadi persoalan yang akan membentuk suatu kondisi yang akan menimbulkan konflik dan pertentangan. Pendidikan Islam multicultural akan membawa segala dampak positif dari perbedaan yang akan membentuk kesatuan dalam bermasyarakat.Pentingnya pendidikan Islam mutikultural di era modern ini adalah untuk menumbuhkan sikap toleransi yang tinggi. Karena dengan adanya kemajuan teknologi yang tinggi di era 
modern ini hubungan interaksi antar sesam tidak begitu menjadi perhatian karena banyak orang yang sudah merasa tidak membutuhkan orang lain. Sehingga tidak ada komunikasi yang yang baik.

Agar pendidikan Islam multicultural dapat berkembang, dibutuhkan prinsip-prinsip yang akan dapat membangun dan membawa pengaruh yang baik. Dalam mengembangkan pendidikan Islam Multikultultural harus mempertimbangkan prinsip-prinsip pendidikan mulitultural dan menunjukkan ciri khas yang ada pada pendidikan Islam.Ada beberapa tantangan yang ada pada pendidikan Islam multicultural yaitu mengenai aspek sosio-kultural, yang menjadi kekhawatiran bahwa multikulturalisme bisa menjadi pemicu lemahnya kepercayaan seseorang terhadap agama yang dipeluknya.Aspek politik, yang berpusat pada bagaimana menerapkan multicultural yang ada pada dunia pendidikan.Aspek pendidikan juga berperan, dalam hal ini ialah komponen lembaga pendidikan, yang mungkin saja masih ada sedikit kebingungan dalam mengelola pendidikan multicultural.

\section{Saran}

Hasil dari penelitian yang dilakukan melalui penelitian kualitatif melalui metode Library Research yang berhubungan dengan isi materi yang telah dibahas, maka ada beberapa saran yang yang dapat disampaikan agar dapat meningkatkan penelitian yang selanjutnya yaitu:

1. Untuk penelitian yang selanjutnya yang menggunakan penelitian Library Research agar memahami judul yang akan dibahas pada penelitiannya karena dengan memahami judulnya, maka akan lebih memudahkan penulis dalam menulis penelitiannya.

2. Penelitian diharapkan agar memahami pengembangan apa yang dapat dilakukan dalam meningkatkan penerapan pendidikan Islam multicultural yang ada di masyarakat.

3. Diharapkan penelitian yang selanjutnya tidak hanya menggunakan metode Library Research saja, tetapi juga melakukan observasi secara langsung agar dapat menemukan data yang lebih akurat.

\section{Daftar Rujukan}

Adibah, Ida Zahara. Madaniyah: Terciptanya Insan Akademis Berkualitas \&amp; Berakhlak Mulia. Madaniyah. Vol. 4. STIT Pemalang, 2016. https://journal.stitpemalang.ac.id/index.php/madaniyah/article/view/ 42.

Cahyono, Heri. "Pendidikan Multikultural” 1, no. 1 (2017)

Edy. "Pendidikan Multikultural Di Sekolah ... Pendidikan Multikultural Di 
Sekolah ..." 6, no. 11 (2017)

Hulu, Indragiri, and Pondok Pesantren. "Penanaman Nilai-Nilai Pendidikan Multikultural Di Pondok Pesantren D DI-AD Mangkoso Barru Sulawesi Selatan" 1, no. 2 (2016)

Ibrahim, Rustam. "Pendidikan Multikultural: Pengertian, Prinsip , Dan Relevansinya Dengan Tujuan Pendidikan Islam." Addin 7, no. 1 (2013)

Jasmani. "Pendidikan Multikultularisme Di Era Modern." Studi Agama Dan Masyarakat 11, no. 1 (2015)

Kamal, Muhiddinur. "Pendidikan Multikultural Bagi Masyarakat Indonesia Yang Majemuk." Al-Ta'lim 6 (2013)

Khalim, Ainul. “Pendidikan Islam Dan Multikultural,” n.d.

Rahman, Abdur. "Pendidikan Agama Islam Dan Pendidikan Islam - Tinjauan Epistemologi Dan Isi - Materi" 8, no. 1 (2012)

Rois, Achmad. "Pendidikan Islam Multikultural Telaah Pemikiran Muhammad Amin Abdullah." Episteme 8, no. 2 (2013)

Ulya, Inayatul, and Ahmad Afnan Anshori. "Pendidikan Islam Multikultural Sebagai Resolusi Konflik Agama Di Indonesia." Ilmu Aqidah Dan Studi Agama 4 (2016)

Yusuf, Mohamad Yasin. "Pendidikan Islam Inklusif-Multikultural." Ta'allum 2 (2014)

Zain, Hefni. "Pengembangan Pendidikan Islam Multikultural." Tadris 8, no. 1 (2013).

Zulkarnaini. “Dakwah Islam Di Era Modern." risalah 26, no. 3 (2015) 